\title{
11. Contestations: Dynamics of precedence in an eastern Indonesian domain
}

\author{
Michael P. Vischer
}

This paper serves as a companion text to the film 'Contestations', which is available online at http://epress.anu.edu.au/precedence_citation.html.

\section{Introduction}

This contribution is concerned with a fundamental issue in the study of human societies: the process by which unequal or asymmetric relations are established, asserted and contested. A second and underlying concern is the development of a comparative method in anthropology, which goes beyond the regional mutually interpretative stance that, in the best of cases, still stands for comparison. In the case of precedence, particular processes of social differentiation involving asymmetric relations can be compared that have been identified as being characteristic to the societies of eastern Indonesia and, by extension, also to the societies of the wider Austronesian world. ${ }^{1}$

This paper investigates one specific case of precedence, the domain of Ko'a on the eastern Indonesian island of Palu'é. The analysis is directed at particular events which occurred in the context of the opening of the ceremonial cycle of the domain of Ko'a. Such cycles were earlier identified as constituting the main order of the domain and the principal arena in which positions of precedence are contested and asserted (Vischer 1996b). ${ }^{2}$

These cycles are carried out only once in a decade and ideally extend over a period of five years. However, periods of intense activity are confined to the opening of a cycle, where water buffalo are purchased on the neighbouring island of Flores and where preliminary sacrifices are held to make amends for transgressions against ancestral law. ${ }^{3}$ Five years later, at the closure of a cycle during its second period of intense activity, the main sacrifice is carried out that ensures the future welfare of the domain. ${ }^{4}$

These events are exemplary in that they are interlinked in a manner highly characteristic of such processes. Furthermore, all of them are connected to earlier events and situations that are traced in the analysis. The language of Ko'a provides a term for this form of tracing which is used mainly in legal context. The term susu refers to the establishment of the history of a given issue, and in practice the more extensive a susu is the stronger the case that can be made in customary courts. This susu process is reflected in the current analysis. The analysis thus 
maintains a strong diachronic perspective as it moves between the level of events and individual actors and the medial level of abstraction of precedence as an analytic concept.

\section{Ko'a Precedence: The First Settlers' Model}

The Ko'a case is exemplary of systems of precedence of eastern Indonesia. In Ko'a, as well as elsewhere in the Austronesian world, precedence is characteristically predicated upon a notion of multiple origins of society. The different groups of the domain maintain different narratives of origin according to which they settled in the domain at different times. There are two different Ko'a origin groups that subscribe to the same myth of origin and creation of the domain, which they have appropriated as the myth of origin of their own group by inserting the names of their own original ancestral pair at its beginning. In this myth, the voyage of the first ancestors is recounted as they travelled from the westernmost rim of the earth to the island. According to the myth, these ancestors brought with them a stone and some earth which, when they had reached the present location of Palu'é, grew to the size of the island as it is now. The myth has the form of a chant consisting of hundreds of paired place-names delineating the path taken by the first ancestors, from the distant point of origin all the way to the domain. In many ways the myth provides a blueprint for the ideology of the first-settling origin groups of the domain, whereby every one of its individual couplets represents a point of access to a different facet of ancestral knowledge. On the basis of literal precedence in the sequence of settlement in the domain, the two Ko'a origin groups that have appropriated the myth of origin and creation, claim ceremonial and political leadership. At two separate centres these origin groups periodically sponsor and conduct the ceremonial cycles of the domain, during which this myth of origin and creation is re-enacted. A successfully conducted cycle then ensures the continuity and welfare of the domain. Although in cosmological terms they both constitute separate centres of the Ko'a universe, in all ceremonial matters one centre always takes precedence over the other. Subsequently settling groups were integrated into the domain by means of marriage alliance. First settlers allocated agricultural land and gave wives to subsequent settlers, which made the latter contextually subordinate to the former. Unlike, for instance, in the case of precedence among the Ata Tana 'Ai of Flores (compare Lewis 1988), where subsequently settling groups constitute a sequential order, oda, the sequence of settlement of the later settling groups of Ko'a is not differentiated, with the exception of one group that holds an intermediary position as traditional wife-givers to the first settlers. This, in a nutshell, is the first settlers' model of Ko'a precedence. 
Figure 1. The ceremonial courtyards of Ko'a

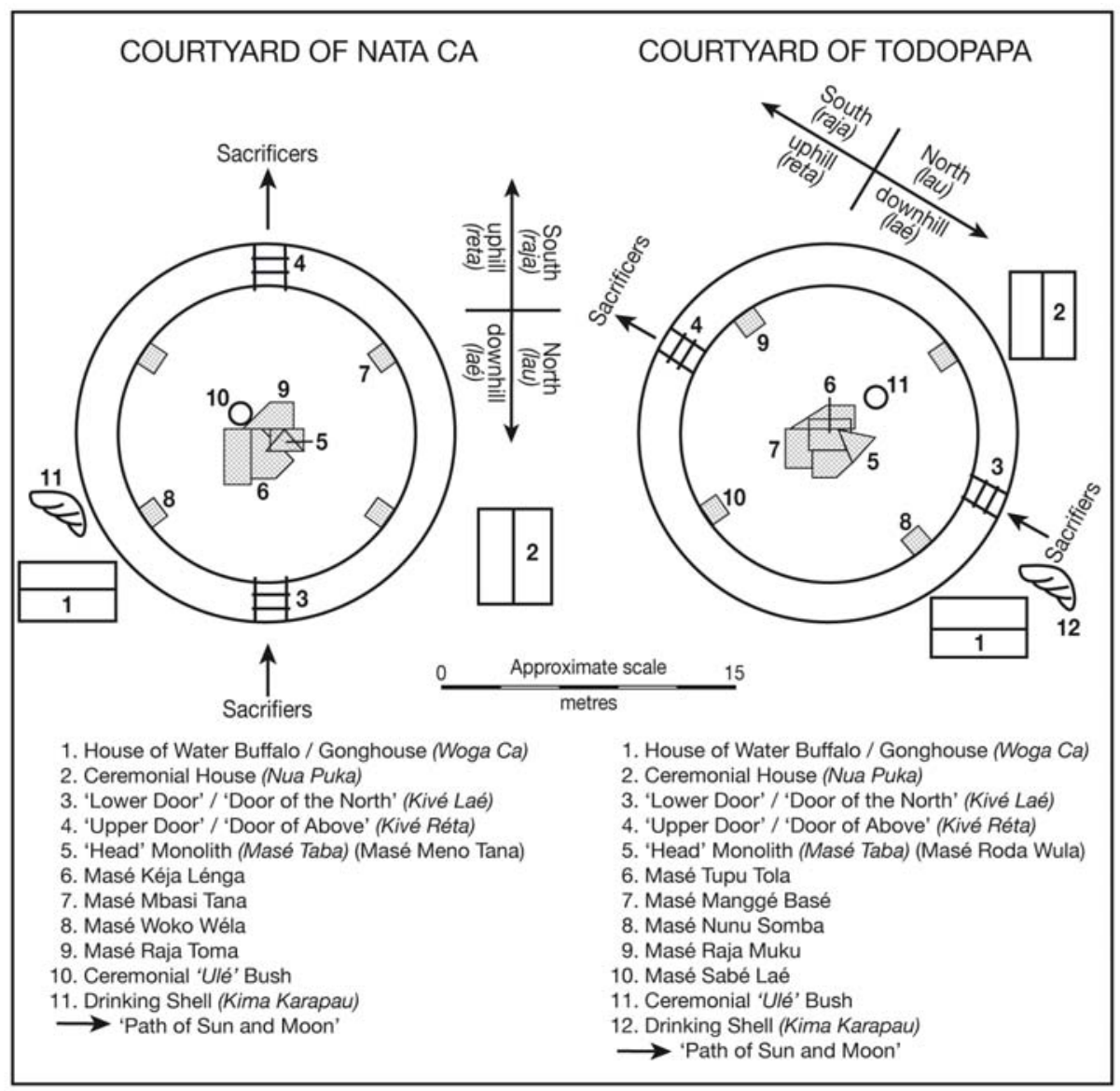

There are two ceremonial centres of the domain, which represent exclusive points of connection with the multi-layered universe. Each of these centres in turn is divided into a lower and an upper half. The houses located at the upper half are associated with the sacrifice of water buffalo and those located at the lower half are associated with the ceremonial purchase of the sacrificial animals. At one centre, all of the ceremonial offices are held by one and the same origin group, whereas at the second centre, these offices are held by two different origin groups. With respect to the localized spirits of the domain, the sacrifiers at the upper half attend to the lower half of the domain and the sacrificers or purchasers to its upper half. 
Figure 2. The Ko'a village grounds: principal houses and ceremonial courtyards

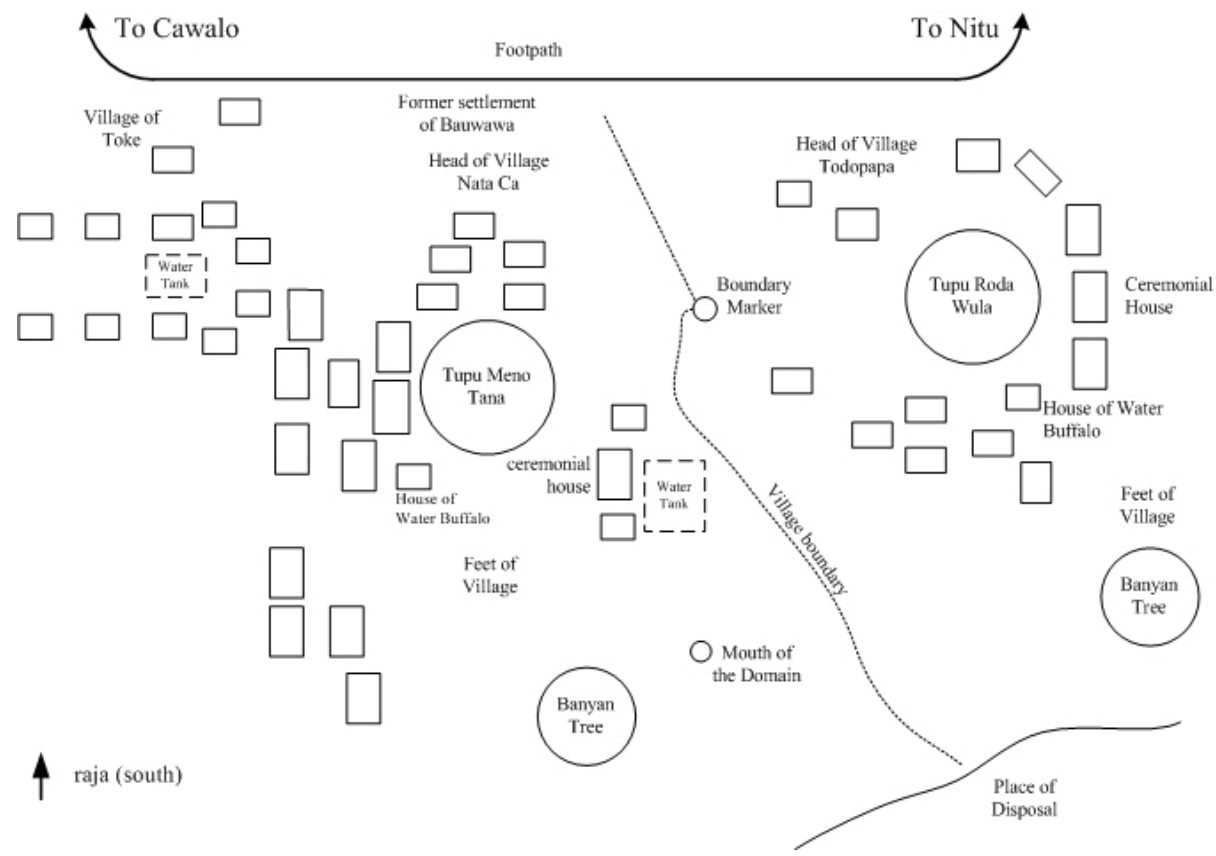

The dwellings of houses of subsequently settling origin groups are arranged in lines in secondary positions behind and along the side of the centres, whereas the dwellings of houses of first-settler status are located in a primary position surrounding the centre. The settlement pattern thus is to some degree an expression of the Ko'a order of precedence.

The Ko'a social order seemed fixed and rigid in the way it was presented to the ethnographer as a first settler's model. The position of the two first-settling origin groups could not be altered in any way. Junior houses of a given origin group seemed to have no option to attain a position of seniority, and within a given house a younger sibling could never become the superordinate first-born son. Although there had been a few vague indications that this order may have looked different in the past, hardly any information could be obtained regarding such changes. There clearly had been changes at the second ceremonial centre of the domain. A few generations ago, the group that used to hold the position of sacrificers or purchasers of water buffalo at the second centre was ousted by its sacrifiers because of incest. The group in question relocated to the first ceremonial centre and no longer assumed first settler status. As a replacement a house of an origin group that did not hold first settler status but an intermediary position was installed as purchaser at the second ceremonial centre. Other than that no changes in the Ko'a order of precedence were ever mentioned. 
The ethnographer's understanding of Ko'a precedence changed significantly, once he had participated in his first Ko'a water buffalo sacrificing cycle (1984-1987). There he witnessed contestations and assertions of positions of precedence not only between the two centres of the domain, but at virtually every socio-cosmic level: At the level of the house, between junior and senior members and at the level of origin groups, between junior and senior houses of the same origin group. There were contestations and assertions of positions of precedence between the two origin groups claiming first-settler status and even between the allied domains of the island. The cycle revealed itself to me as a total social phenomenon in the Maussian sense, involving all levels of Ko'a society. It constituted the main arena in which positions within the order of precedence of the domain were contested, and the holders of those in turn were continuously engaged in asserting their position. ${ }^{5}$

\section{The opening of the Ko'a sacrificing cycle of 1994}

I should have known that Opa, the main priest-leader of the domain, had a hidden agenda when he invited me to return to Ko'a to film the opening of the last water buffalo sacrificing cycle. It was in early 1994; I had just completed the study of the major corpus of texts connected with that cycle. In fact, I was hoping to conclude my fieldwork on Palu'é and if anything, this offer seemed to be a clever way to lure me back to the domain. When I returned six months later on the date we had agreed upon, everybody in Ko'a was worried. The main priest-leader's daughter, a young unmarried woman called Mia Poké, had not returned yet from Malaysia, where she had been spending most of the year cooking for her labour migrant brother Sundu. At that time Mia Poké was virtually the only person eligible to take on the office of ceremonial virgin for this cycle. This officiant is regarded to be the spouse of the main sacrificial water buffalo. At various stages of the cycle she goes into seclusion and following the sacrifice the same stringent mortuary restrictions apply to her as they do to any woman who has lost her spouse. In principle any unmarried woman of a house of first-settler status that is engaged in the purchase of water buffalo can be selected for this office, on the condition that a major part of the bridewealth for her mother has already been paid. However, at that time there was no other candidate. So without Mia Poké's presence the cycle could not be opened.

It was the beginning of the rainy season and the seas were turning rough, and with every day that the voyage was delayed the trip would become more dangerous. As the main priest-leader's younger brother by way of adoption, the task fell to me to get Mia Poké back from Malaysia. ${ }^{6}$ It took several weeks to trace them in Malaysia and another couple of weeks to convince Mia Poké and her brother Sundu to come back. No doubt the prospects of being greeted in Flores by a camera crew as they alighted from the boat helped convince them to come. When they finally had arrived, they did not join me on the boat back 
to Palu'é but stayed on for a few more days in the district capital of Maumere on Flores as they said, to do some shopping, seemingly oblivious to the fact that all of Ko'a was anxiously waiting for them.

A few days later, the Ko'a priest-leader's firstborn son Sundu and his sister Mia Poké entered the village. Only minutes after their arrival we witnessed the first scene of contestation to the Ko'a order of precedence. ${ }^{7}$ Sundu walked straight up to the grave site of his recently deceased foster mother, a woman called Moré. There he dropped to the ground and began to cry. Two classificatory grandmothers hugged and comforted him while another one could be seen sitting on the porch of the priest-leader's house next to the grave site. She lamented that, although he had not been ill when he was informed that his foster mother was dying, he had not come home. Then Sundu's father, the main Ko'a priest-leader arrived and took his son, whom he had not seen for many years, into his arms and they wept together. The father then moved towards the porch where his daughter Mia Poké was sitting. As they embraced, both were crying.

Meanwhile, inside the priest-leader's house several of Sundu's classificatory mothers were opening a small basket containing the fingernails and hair locks of the three last generations of deceased members of that house. These are the named ancestors that a given house can draw on for support in its daily undertakings. The women were looking for the relics of the recently deceased Moré. Lisé, a classificatory brother of the main priest-leader Opa joined in the search and began to unwrap a small parcel containing Moré's fingernails. The women asked him not to open it. As he grabbed the parcel they begged him not to take it outside. He insisted, saying that he was taking it outside to show it to the priest-leader's son Sundu. Weeping himself now, he handed the parcel to Sundu. Walking together to the front part of the house they held on to each other and Sundu exclaimed in tears that his foster mother Moré was truly dead. The key to understanding this emotionally charged scene is to be found in the troubled relationship between Lisé and his classificatory brother Opa, the main Ko'a priest-leader. 
Figure 3. Kinship diagram of Opa and Lisé (abbreviated)

Powo Origin Group

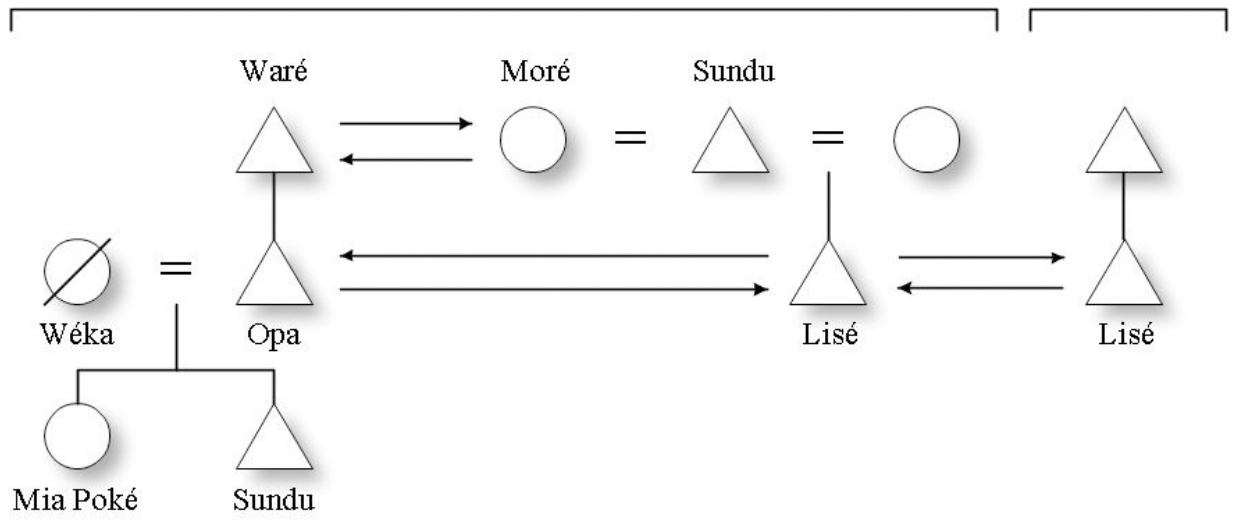

The troubled relationship between Lisé and Opa has some of its origins in the common practice of child transfer. Children often choose to eat and sleep in another house of the same origin group, and that is considered to be quite normal. If a child ends up spending extended amounts of time in a particular house it will after a while be considered to be a member of that house. In the case of Opa and Lisé there was something of a switch-over going on. As a young child Opa apparently spent a lot of time in the house of Lisé's father Sundu, who used to be the local government representative in Ko'a and Lisé in turn spent a lot of time in the house of Opa's father Waré, who held the position of main priest-leader. So when they still were young, at times Opa would be considered to be Sundu's son and Lisé would be considered to be Waré's son. This situation was further complicated by the fact that Lisé had chosen not just one, but two alternative houses in which to spend his time, and the second house was a house of a different origin group. Eventually Lisé gained rights to land use in that origin group, and when Opa's father Waré died, he also laid claim to a specific lot of land held by Waré's house. Opa contested that claim in court but the court solomonically divided Waré's lot in two, awarding one half to Opa and the other half to Lisé. 
Moré, the woman Sundu and Lisé had been crying for, followed a similar pattern. Initially she was considered to be Sundu's wife, because Sundu had paid a considerable amount of bridewealth, but at times she also stayed in Waré's house. Since she could not bear any children, this did not give rise to any conflicts. Being barren, she was not really regarded as the spouse of either. When Opa's first wife died, it was Moré who took care of the two children, Mia Poké and Sundu. Because in her youth she had been instructed by a renowned ritual specialist, Moré also handled some of the ritual affairs connected with the ceremonial centre, albeit only on behalf of the main priest-leader.

Opa and Moré never got on well and apparently before her death they had been fighting about Moré's scheming to find an appropriate spouse for Sundu. Moré was hoping for an alliance between Sundu and one of the houses of her own natal origin group, an alliance that would be very much in line with Ko'a presciptive alliance.

In seeking to broker a marriage for Sundu, Moré was aiming at re-instating her natal origin group as the traditional wife-giver to the first-settling groups of the domain. Such marriages had become rare and for a number of reasons her natal origin group was becoming more and more insignificant. In the past, Moré's natal origin group had held much more of a prominent position in the order of precedence of the domain. As the traditional wife-givers to the priest-leaders, they were in particular contexts even superordinate to them. According to their own origin myth, they had brought the technologies of fire, metal and weaving to Ko'a and for that they had received the special right to act as custodians of the ceremonial house of the main ceremonial centre of the domain. This is also the house the ceremonial virgin inhabits during periods of seclusion. However, the custodians of the ceremonial house were dying out, and in the absence of successors, custodianship would fall back to the first settlers and so would the prestige that went with this custodianship. A marriage of her natal origin group with the priest-leader's son, who would be the next main priest-leader of Ko'a, would counteract this impending loss.

For several reasons Opa felt that such an alliance would not be desirable. In this intrigue, Sundu sided with his father Opa, whereas his sister Mia Poké sided with Moré. Much of this dispute took place in the absence of Sundu, who for a number of years had migrated to Malaysia to work in a timber camp. During all that time, Mia Poké was being instructed in ritual matters by Moré. When Moré died and Opa refused to pay for the mortuary costs, his daughter Mia Poké apparently left Ko'a in anger to go, as they say, 'to cook for her brother' in Malaysia. Opa felt that since Moré had been Sundu's spouse and since Lisé had inherited Sundu's land holdings, it was up to Lisé and not him to provide pigs for Moré's funeral. ${ }^{8}$ So that was one of the reasons why Mia Poké had not wanted to return to Ko'a to take up her office as the ceremonial virgin for the new cycle. 
She saw an opportunity to contest her father's position and did just that, thereby effectively preventing the domain from opening a new ceremonial cycle and endangering the welfare of all of its members.

Seen in this context, my somewhat flattering invitation to come to Ko'a and film the cycle appears to have been part of Opa's strategy to get his daughter back. I was the one in the family, so to speak, who had connections in the outside world and who could perhaps effect her return. Given that I had committed myself fully to the project, he knew very well that I would be trying my best to get her to come home. Perhaps he also hoped that Mia Poké would be intrigued by the possibility to be filmed in her identity as a ceremonial virgin. Opa's ruse had worked. Interestingly, no one in Ko'a seemed to wonder if perhaps one of the reasons why Mia Poké did not want to return was that she did not want to become a ceremonial virgin in the first place.

One event that occurred during the opening phase of the cycle does provide an indication of Mia Pokés ambivalent disposition with regard to her office as kombi virgin. During the cycle, which ideally extends over a period of five years, she is regarded as the spouse of the sacrificial water buffalo and is, therefore, not eligible for marriage. Once the main sacrifice at the end of the cycle has been carried out, she is still not free to get married, but is subject to the same mortuary restrictions generally applied after the loss of a spouse. Even after these restrictions have been lifted, the bond to the water buffalo remains intact. Should anyone wish to marry her, special payments in addition to the negotiated bridewealth must be made to buy her loose from this bond. This arrangement acts as a deterrent to potential suitors and effectively precludes any opportunities for marriage the young woman might have. At the opening and at the closing stages of the cycle, the kombi virgin goes into seclusion in the small ceremonial house adjoining the centre her water buffalo is affiliated with. There, she is attended to by a female member of that house. Particularly during the purchasing voyage, she must remain absolutely still, to the point that her attendant must feed her when she is hungry and scratch her back when she is itching. As the old lady attending to her during that part of the cycle pointed out before the purchasing parties departed, whatever movement Mia Poké might make has a detrimental effect on the boats as they are out at sea. In the event, the boats unexpectedly met with stormy weather soon after they had left the island. Sudden gusts of wind tore up the sails of her father's boat and the boats of both purchasing parties were dispersed. As the winds hit, those on board anxiously called out for Mia Poké to remain still, fearful that the adverse conditions were being prompted by movements the kombi virgin was making in her seclusion back home. All boats eventually did reach Flores safely, but the weather remained stormy for six days and nights and prevented them from returning to Palu'é. During the return trip there was more bad weather, but miraculously none of the small vessels capsized in the rough seas, even though they were loaded well 
beyond their capacity. Finally, at the end of the trip, as the boats prepared to unload the animals at the Ko'a beach, one of the boats did capsize. (This event will be discussed in detail below.) One of several lines of explanation offered for this incident was that the kombi virgin had not remained completely still in her ritual seclusion. Eventually other lines of explanation for the incident were favoured, but upon returning to the villages there was talk that Mia Poké had not stayed in seclusion during all of the seven days of the purchasing voyage and that she had been seen playing around with her friends, while her father's party was out at sea. Clearly Mia Poké had some resistance against the restrictions imposed upon her by her office.

In order to understand Opa's refusal to pay for the mortuary costs of Moré as an act of assertion of his primary position within the Ko'a order of precedence and in order to appreciate Lisé's tearful display as an instance of contestation, we must turn to yet a further set of events of the past. Here Lisé exploited this grey zone created by his moving back and forth between Sundu and Waré's house during his childhood. According to hada, the ancestral corpus of rules and regulations, the first-born son of the most senior house of the first-settling origin group is eligible for the office of main priest-leader. Lisé was indeed a few years older than Opa and yet he was not the main priest-leader of Ko'a.

Apparently, three cycles ago, that is roughly thirty years earlier, Lisé had made an unsuccessful bid for priest-leadership. Working in concert with a man called Lopo, the priest-leader of the second ceremonial centre of the domain, he had gained support from the main priest-leader of the domain of Cawalo, a traditional ally of Ko'a. The main priest-leader of that domain was a staunch opponent of Opa's, who would have liked to have seen Lisé, who had a much weaker and more malleable personality, in the position of main Ko'a priest-leader (see Vischer 1996b). At the time, the people of Ko'a enthusiastically followed Lisé and his allies to purchase water buffalo on Flores, thereby showing their approval for this new main priest-leader of their domain. Lisé's sacrificial animal, however, did not survive. This was generally interpreted as a sign that the Supreme Being and the ancestors of his origin group did not agree with Lisé's bid for priest-leadership. The event is hardly ever mentioned in Ko'a, perhaps because there is a certain sense of embarrassment for having so easily shifted loyalties from one priest-leader to the next, only to have to embrace again the one they had rejected previously. The supernatural sanction, of course, also strengthened Opa's position considerably. Ever since then, Opa has used every opportunity to humble Lisé publicly, as he did by refusing to contribute to the mortuary payments for Moré. In refusing, he was pointing to the fact that Lisé was to be considered Sundu's son and, therefore, fully responsible for the mortuary payments for Sundu's deceased wife. Opa, however, seemed to want things both ways. On the one hand he rejected responsibility for Moré, but on the other hand he kept her fingernails and hair locks stored together with those 
of his own ancestors in his house. Lisé's crying as he clutches these relics seems to be saying: 'Behold the injustice that has been done to me. I have been badly cheated. I paid for Moré's funeral, but look, it is he and not I who gets to keep her relics (in order to be able to draw upon her support as an ancestor of his own house)'.

Here we can identify one of the important strategies in the processes of assertion and contestation. If customary regulations, such as those pertaining to mortuary issues have been breached and no supernatural sanction has ensued, this indicates the action has been approved by the ancestors and the Supreme Being. Such a breach of custom actually strengthens the position of the offender. ${ }^{9}$

One such instance, where Lisé's actions nearly resulted in humiliation and subsequent loss of status, took place at the very end of the water buffalo purchasing voyage. In the unloading of the sacrificial animals at the Ko'a harbour, the order of precedence between the two ceremonial centres of the domain must be maintained strictly. The sacrificial animal for Opa's centre is always to be unloaded first, followed by that of Lopo's, the second priest-leader of the domain. Upon unloading, the tether of the sacrificial animal must be passed to a member of a particular origin group that holds rights over the harbor of Ko'a. That origin group then guides the water buffalo along a particular path up the mountain to the boundaries of the village where the tether is passed on to the main priest-leader. He then takes the animal up to the boundary of the second ceremonial centre, where he hands it over to that priest-leader, in line with the order of precedence between the two centres. Any mistakes in the unloading or in the sequencing of the tether can result in the death of the water buffalo. It is during this first stage, following the unloading, that the water buffalo that Lisé had brought back twenty years earlier had died. On this most recent occasion Opa delegated the unloading to Lisé. ${ }^{10}$

In the event, Lisé unloaded first the main sacrificial animal of the cycle, the 'water buffalo of the domain' (karapau tana) affiliated with the main ceremonial centre. This is the animal that is to be raised in Ko'a and sacrificed, ideally after a period of five years, at the conclusion of the ceremonial cycle. Following the 'water buffalo of the domain', Lisé unloaded two more animals affiliated with his centre. These animals are referred to as ' $<$ water buffalo $>$ to sacrifice and throw away' (pati kao), in allusion to the fact that following their sacrifice at the opening of the cycle their carcasses are left on the ground to be scavenged by outsiders. In the cycle in question there were a number of such animals which were to be sacrificed as atonements for transgressions against ancestral prescriptions. The specifics regarding these animals will be discussed further below. Just as Lisé was unloading them, the boat carrying the main sacrificial animal of the second centre capsized. Fortunately for Lisé, the animal, which was trapped in its cage, survived the ordeal. Had the animal died, a new 
purchasing voyage would have had to be initiated to replace the 'water buffalo of the domain' of the second ceremonial centre.

At the time, several explanations for the capsizing were offered in Ko'a. Some of the participants at both centres speculated that the incident took place because Lisé had unloaded both, the main sacrificial animal of his centre as well as those dedicated to the preliminary sacrifices in one go, rather than allowing the second ceremonial centre to unload its own main sacrificial animal right after the main sacrificial animal of the first centre, and only then unloading the other animals. Such a sequence would have been more in line with the order of precedence of the domain, where any ceremonial activity always must be initiated by the first centre, after which the second centre is permitted to commence the same activity. As it is commonly put in Ko'a, the first centre always must 'go forth' (nolo), whereas the second centre always must 'follow' (tetu). Breaches generally involve significant supernatural sanction and can also entail legal consequences. Had the animal died and had this line of argumentation prevailed, it is more than likely that Lisé would have had to be the sole sponsor of a new purchasing voyage, an undertaking that doubtlessly would have put him deeply into debt. Furthermore, the public ridicule possibly would have reduced his status for good. As it turned out, on that particular occasion Lisé was fortunate and his blunder did not have immediate consequences. ${ }^{11}$

\section{Incest and Precedence}

During the previous Ko'a ceremonial cycle of 1985-1988, Lisé had not been quite that fortunate. At the beginning of that cycle, soon after the main sacrificial animals had been ceremonially installed in the domain, the water buffalo of the domain, which was affiliated with the main ceremonial centre, suddenly died. At the time divination revealed that the animal had died because Lisé had committed incest with a classificatory sister residing in an allied domain. Not only was he obliged to sponsor a new purchasing voyage to replace the main sacrificial animal but he was forced to purchase a second animal, which was to be sacrificed for his transgression (see Vischer 1996b).

The incident indicates that the accusation of incest, particularly between members of first settling houses, may be another strategy that can be resorted to in the contestation or assertion of positions of precedence. At any point in time there is a number of marriages in the domain that, strictly speaking, could be considered to be 'wrong marriages' (vai cala), either because the alliance was contracted across generations or between classificatory siblings. However, only rarely are such cases contested, unless an occasion arises, where a particular advantage can be gained, as had been the case with Lisé's transgression.

In this light, the reason given for the ousting of the origin group responsible for the purchase of water buffalo at the second ceremonial centre of the domain 
acquires new significance. A number of generations ago, this origin group had been accused of incest and was driven away from its centre. At the time, the two halves of this centre were traditional partners in marriage alliance. It is, however, not clear which group held the position of wife-taker and which that of wife-giver. More likely than not, the direction of alliance was periodically inverted (see Vischer 1992). According to the scanty information available, the members of the ousted group were about to move to a different domain, when the priest-leaders of the main Ko'a centre invited them to settle in their part of the domain, albeit without retaining their first settler status.

In doing so they became members of the category of subsequent settlers commonly referred to as 'women of eight' (vai valu), a term, which also denotes widows and orphans, the rationale here being that all the members of the domain go into mourning at the death of one of its priest-leaders. The complete ritual speech couplet, which refers to those members of a domain that do not hold first settler status, is 'women of eight // children of halo' (vai valu // hana halo). The first composite term of this couplet refers to the Ko'a notion of gestation, where female children are born eight months after conception, whereas the period of gestation for male children is nine months. Subsequently settling groups in the domain are thus conceptually female. According to Ko'a classificatory thought they are, therefore, subordinate to the conceptually male first settlers. The second half of the couplet refers to a related contrast, where subsequent settlers are classified as 'child people' (hata hanané), as opposed to first settlers who are classified as 'father people' (hata hamané). The term halo is a reference to a myth of origin subscribed to by a number of different origin groups on the island, which points to a region in neighbouring Lio on Flores as a place of outside origin. This clearly identifies them as subsequent settlers.

The two houses that subsequently stepped into the vacant positions at the lower half of the centre do not maintain alliance relations with the upper half of that centre, as had been the case with their predecessors. Rather, they sought alliances with the origin group in charge of the main ceremonial centre of the domain. This relationship is in line with the traditional position of their original origin group, which in this process of replacement they had split off from, as wife-givers to the first settlers of the domain.

During the most recent Ko'a cycle, another case of incest between first settlers was sanctioned. This case was far from arbitrary, in that it involved two siblings who had been born from the same parents. About fifteen years ago, Cawa, a man now in his late thirties had left Ko'a to seek work in the Malayan state of Sabah. More than a decade later, his young unmarried sister Wéka went to join him there to assist in his household. As it was explained to me in Ko'a, when he had left home Wéka had been still a little girl, so the two never had known each other as adults. In Sabah they had sexual relations and eventually they conceived 
a severely handicapped child. Although initially they tried to hide this fact from other Ko'a migrants, the news eventually got back to Palu'é.

Unless incest has occurred between members of first settling houses, the sanctions called for by ancestral law are relatively light. Sleeping mats on which the transgression has occurred are burned and a pig from the house in question is killed on its door step. Instead of allocating individual cuts to particular related houses, as is usually the case, the cuts are thrown across the roof to the back of the house, where they are gathered up by human scavengers.

Incest between first settlers is altogether a different matter. Because of the close affinity constructed between members of first settling groups and the domain itself, incest between these can cause earthquakes, volcanic eruptions and tidal waves (see Vischer 2001). In pre-colonial times the culprits would have been sacrificed at the top of the volcano in order to avert such natural disasters, whereas nowadays water buffalo are employed as a replacement.

In Opa's speech to the people of the domain, which immediately preceded the sacrifice of the incest buffalo on the volcano, the main Ko'a priest-leader couched the issue in terms of morality and responsibility. ${ }^{12}$ He began by making allusion to the mythical foundations of incest sanctions and mentioned the story of Noni and her brother Karé who 'swam together' (that is, had sexual intercourse) in the lake inside the volcano, as a result of which the "mountain descended and the sea rose up' (that is, natural disaster ensued). ${ }^{13}$ He pointed out that in the case of Cawa and Wéka, their father Rugu and his brother Sundu had to pay for the sacrificial animal, in order 'to keep the mountain up and the sea down' (that is, to avert natural disaster) and that this should be a warning to anyone whose children were working in Malaysia, lest their children 'play with the wrong drums and gongs' (that is, have incestuous sexual relations). Implicit in this last statement was the notion that henceforth incest among members of houses that were not of first settler status would be fined in the same way as first settlers. Understandably, this new regulation was not welcomed by the members of the domain.

A third water buffalo was sacrificed for transgressions against ancestral prescriptions two days after the incest sacrifice. This sacrifice, which took place at the main ceremonial courtyard of the domain, is referred to as ' $<$ the water buffalo of $>$ the arm span of the earth' (repa tana). Its designation refers to the notion that for any deep cavities, such as excavations occurring during construction activities (ideally, cavities that exceed a depth of one arm span), a water buffalo must be sacrificed. At every cycle one such animal is sponsored by all Ko'a houses, rather than only by its first settlers, since all members of the domain have in one way or another been involved in construction activities during the years following the closure of the previous ceremonial cycle. 
The underlying cosmological notions for this sacrifice are linked to the conception of the island as a living body, beneath the surface of which blood flows, as it does through the human body (see Vischer 2001). The embodied domain weakens at every instance that cavities are inflicted upon it, eventually resulting in loss of fertility. Only blood sacrifice can heal these 'wounds' and restore the integrity of the incorporated entity. A sick body is conceptualized as being hot. The sacrifice of animals is aimed at removing this heat and at reattaining a state of beneficial coolness. Thus, to heal the wounds of the domain a water buffalo must be sacrificed at the opening of each new ceremonial cycle. Ko'a first settler ideology constructs a close affinity between the blood flowing beneath the surface of the domain, the blood of its first settlers and the blood of the sacrificial water buffalo. In the 'repa tana' sacrifice, the blood of the animal shed at the ceremonial centre is viewed as a substitute for the blood of its main priest-leader. This came out clearly at the end of the speech given by the main priest-leader at his ceremonial centre, immediately preceding the sacrifice. ${ }^{14}$ In his address he first made allusion to the incest sacrifice and repeated his earlier admonitions, because some of the members of his domain, as well as many members of allied and neighbouring domains present on that occasion, had not been able to attend the sacrifice at the top of the volcano. He also asked those who had come from outside mainly in order to scavenge, to be patient and to enjoy themselves and socialize before they cut up the carcass, the reason being, that by allowing the blood to penetrate fully into the ground the efficaciousness of the sacrifice is increased. The central statement of his speech dealt with the reasons for this sacrifice: that the embodied domain had been harmed through the collective actions of its people and that it was everybody's responsibility to conduct this water buffalo sacrifice, rather than for him to sacrifice himself. He said: "I do not agree to sacrifice myself, I do not consent to give up my body. I replace my body; my cuts fall to the ground. I replace my blood; my blood pours down." Implicit in this statement was again the strong identification of the priest-leader with the domain. If the domain is not healed through sacrifice, then its priest-leader in turn can become ill and may even die (see Vischer 2001).

The repa tana sacrifice and the sanctions for incest among the first settlers both highlight clearly the privileged cosmological position of members of first settling origin groups in the domain. As such they can be understood as periodically recurring assertions of precedence. However, one might argue that the extension of the costly sanctions for incest among first settlers to all members of the domain announced in Opa's speech at the top of the volcano ultimately would undermine this special position, because such an extension implicitly accords the same cosmological ramifications to the actions of subsequent settlers as it does to first settlers. This is perhaps why to date this new regulation has never actually been applied. 


\section{Origin, Place and Precedence}

On the day following the sacrifice at the top of the volcano, the very same people who had been fined for this case of first settler incest were called upon to provide yet another water buffalo, this time to make amends for a different type of transgression. The sacrifice was held at a place called Powo, a location, which is of central importance to the identity and status of Opa's origin group as first settlers. Powo is the original place of settlement of this group. The place, which according to the Ko'a myth of creation, grew out of the stone and soil the first settlers had brought along with them on their mythical voyage from the western rim of the universe. As such it is virtually an icon of their precedence in the domain. Powo was abandoned many generations ago, when the various origin groups of the domain moved from their separate and dispersed places of original settlement to form the two current main Ko'a villages, Nata Ca and Todopapa.

In everyday speech, the abandoned place of original settlement is simply referred to as Powo and the group that subscribes to this place as its place of origin, as Hata Powo, People of Powo. The full name of this origin group, which is used only in formal contexts, consists of a string of place names denoting a patch of sacral forest surrounding the ceremonial centre of the abandoned first settlement. The trees of this forest are the home of a particular supernatural being that can be addressed only by the Powo priest-leader. This being has pendulous breasts which, during a drought, are slung across her shoulders. Through cracking open a coconut on one of the monoliths of the abandoned centre, her breasts can be made to fall off her shoulders. This immediately results in heavy rainfall throughout the domain. Because of this supernatural presence linked to the provision of rain, which is of the highest importance in a predominantly agriculturalist society, it is prohibited to cut down any trees inside the sacral forest of Powo. Any disturbance could cause this being to flee, leaving the main priest-leader without the means to influence the fecundity of the domain.

Powo has been a place of contention for some time. Ownership and rights to usufruct are shared by all of the houses of the Powo origin group. In the past, members of those Powo houses associated with the upper half of the main Ko'a ceremonial centre and thus with the act of sacrificing water buffalo, have attempted on several occasions to clear the Powo forest. Powo is located at only a short distance from the Ko'a settlements, and because the land has never been used for agricultural purposes, its soil is a lot more fertile than that of most other parts of the domain. Partly for those reasons, some of the sacrificing houses of Powo dearly wish to turn the forest into agricultural land. ${ }^{15}$ Misfortune occurring in the sacrificing houses following any attempts in clearing have to date acted as deterrents to further clearing. However, to the Ko'a main priest-leader, such attempts to clear Powo are viewed as a direct challenge to 
his position. They undermine one of his crucial functions as priest-leader, to provide the domain with rain in times of need.

In a speech at Powo addressed to the members of the domain and to the crowd of visitors from all over the island, the main Ko'a priest-leader explicated the reasons for this sacrifice which was about to take place. ${ }^{16}$ He began by invoking the paired formal term for fire making sticks (poco no'o laci), which according to ancestral law stands for the unlawful burning off of land. He mentioned that twice in the past Powo had been burned down accidentally by the same people, while they were clearing gardens surrounding the forest. He went on to state that the offence had been perpetrated by the very same houses which had only just been fined for incest. Properly speaking, he said, they should be liable to sacrifice two animals at Powo in addition to the one already sacrificed on the volcano. However, because they were related through marriage, the fine would amount to just two animals: 'one for above (the volcano) and one for below (Powo)'. Finally he threatened to fence off the sacral forest, an action which would close an important path leading to gardens located above the Powo forest. Although it is generally not permitted to close or relocate any of the paths in the domain, he insists that his origin group had already resorted to such measures in the past. This last statement was received critically by the people of Ko'a and there was some resentment about this assertion of precedence, because of the disruption of everyday agricultural activities such a measure would entail.

Figure 4. Kinship diagram of Opa/Wéka and Rugu/Sundu (abbreviated)

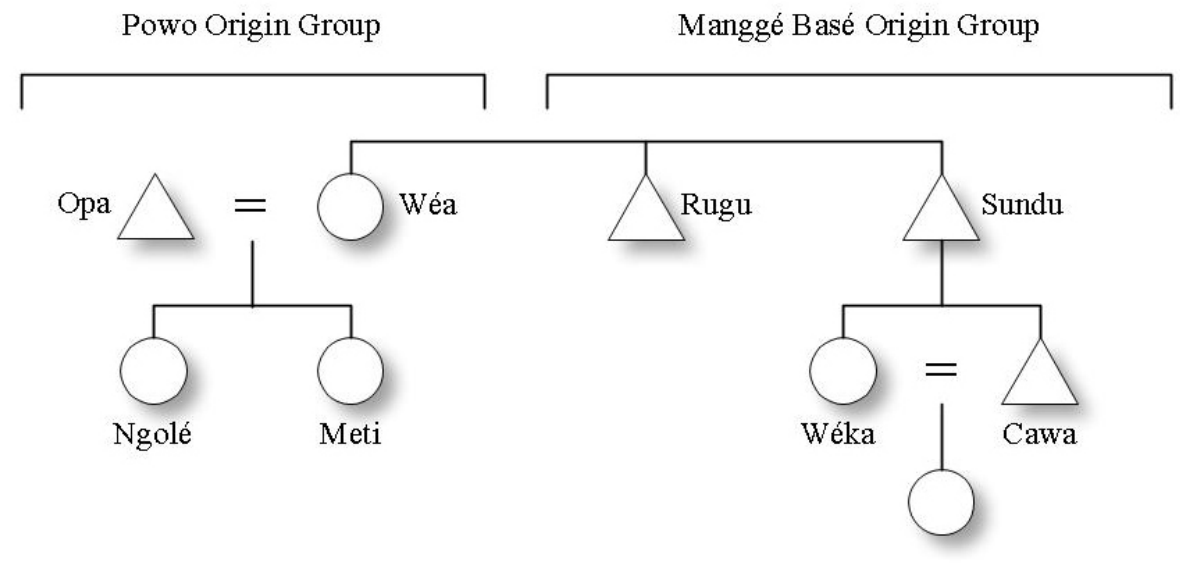

The relatedness Opa was referring to in his speech pertains to his second marriage to a woman called Wéa, a sister of Rugu, the very same man who had been fined for the incestuous relationship in which his brother's children had engaged in Malaysia. Opa had had two daughters with Wéa, both of whom were 
in their early teens. Being unmarried and of first settler status, they would have been appropriate candidates for the office of kombi virgin. However, because Opa had never made any significant instalments of bridewealth to their mother's natal house, they were not eligible for that office.

Generally, defaulting on bridewealth instalments eventually entails supernatural sanctions for the wife-taking house. Opa and his wife-givers could, therefore, well have interpreted the accidental burning of the Powo forest as such an instance. The possibility was, however, never publicly voiced. Although Rugu's house was also of first settler status and a member the sacrificing houses of the second Ko'a ceremonial centre, it had a junior position within that origin group and even though wife-givers are in some contexts superordinate to wife-takers, Rugu did not stand up to his wife-taker and demand that bridewealth be paid. In this instance, the amount of bridewealth owed to him by Opa was actually reduced by the fact that it had been Opa who had paid for the two animals that had been sacrificed on behalf of Rugu's house. Rugu himself would have been hard pressed to provide the necessary funds for these sacrifices and, therefore, had to agree to reduce the amount of bridewealth owed to him, by accepting the two animals in lieu of the ivory tusks, golden ear pendants and large pigs customarily given to wife-giving houses. Having accepted these, it was not likely he would be receiving any further instalment of bridewealth in the near future. In this particular case, Opa managed to turn a potentially threatening situation into a distinct advantage. By staging these highly visible sacrifices that emphasized the privileged cosmological position of his group and the primacy and sacredness of its place of origin, he asserted very effectively its position of precedence in the domain, while at the same time reducing the amount of bridewealth he owed to his brother-in-law.

Apart from this underlying issue of bridewealth, there is yet another aspect to the two buffaloes sacrificed for the transgressions of Opa's wife-givers. In both instances, immediately preceding the sacrifice, the tether of the sacrificial animal was passed through the cracked bamboo wall of Opa's house and placed on his house altar to inform his ancestors and the Supreme Being of the impending sacrifice. ${ }^{17}$ Strictly speaking, the priest-leader of the second Ko'a ceremonial centre or the senior house of the sacrificers of that centre should have been doing this at their own house altar, since the offences had been committed by members of the sacrificing origin group affiliated with that centre. At least with respect to the incest sacrifice, the responsibility clearly was with the second centre. It is not altogether clear why this matter was handled in this way. The pragmatic reason given by Opa was that it had been he who had purchased those animals and brought them in from Flores. The implication is that neither the sacrificers nor the priest-leader of the other centre had made any moves to atone for their transgressions, leaving it up to him to avert the supernatural sanctions that threatened the whole of the domain. In a way his responsible, but also somewhat 
self-righteous, action amounted to an assertion of his precedence over the second Ko'a centre. There is, however, also a cosmological angle to this issue. According to Ko'a ideas about the afterlife, the deceased members of the domain reside inside of the volcano. There they lead a life which is very similar to that of the living, except that the dead experience neither pain nor hunger. The placement of the tether of a sacrificial animal on the house altar enables the deceased members of that house to conduct their own ceremonial cycles and tend to their social network among the dead by exchanging various categories of goods. Ancestors who are successful in these undertakings in turn can give strong support to the living members of their house in their dealings in the world of the living.

\section{Ritual, Precedence and Marriage Alliance}

Another line of argumentation that was raised with regard to the near disaster that occurred during the unloading of the sacrificial animals at the end of their voyage from Flores, one taken by members of the main ceremonial cycle, involved a further facet of the notion of maintaining the order of precedence between the two centres, where virtually every ritual activity is commenced first at the main ceremonial centre and then only followed by the second centre. This refers to an incident that took place at the beginning of the purchasing voyage, during the crossing over to Flores. ${ }^{18}$ The small fleet comprised of boats of both centres was dispersed due to bad weather shortly after departure from Ko'a. Those boats affiliated with the main Ko'a centre sought safety for the night in a cove along the Flores north coast. On the following morning, upon arriving at its final destination, the main purchasing party found that the boats of the second party had arrived there before them. Although there was no direct evidence indicating that this had been intentional, the inversion of the proper sequence of arrival did constitute a considerable breach in the order of precedence between the two centres. The capsizing of the boat carrying the main sacrificial animal of the second centre, therefore, was to be interpreted as a warning by the Ko'a Supreme Being to maintain the order of precedence between the two centres.

On a personal level Opa did not get on well with Lopo, the priest-leader of the second Ko'a centre. To Opa, Lopo was ignorant in ritual matters and, unlike himself he had no privileged connection with the Supreme Being. He was an outsider whose ancestors had been placed in their current position as a result of the case of incest. For virtually every ceremonial activity at his centre, he depended on the instructions of Pali, an old lady, who was a prominent member of its sacrificers. Furthermore, Opa was well aware of the fact that Lopo in the past had been giving Lisé support in his ambitions to become main Ko'a priest-leader. Lopo had even married a sister of Lisé, which in particular contexts placed him in a subordinate position with regard to Opa's origin group. Generally, 
first settling origin groups are not supposed to be linked by marriage alliance, partly for that very reason.

After the controversial incidents of the purchasing voyage, Opa used the first opportunity that presented itself to assert his position. Once the sacrificial animals have been brought to the domain, the priest-leader of each centre calls the collective ancestors and the Supreme Being to his respective centre in a ritual referred to as kao pollo, which translates as to 'divide and to throw away'. During this ritual the pervasive dual socio-cosmic order of the domain is explained, hence the appellation 'to divide', and a commitment is made in the presence of the Supreme Being about the date of the final sacrifice. This division of the domain applies not only to its two ceremonial centres, but also to the internal division of each centre into an upper and lower half. (see Diagram No.1).

In a playful rice throwing battle between the upper and lower halves of each centre, the Supreme Being and the localized collective ancestors of the domain are invited to attend. These ancestral spirits are closely associated with particular named locations, referred to as 'the names of the domain' (tana ngarané). Female officiants of the upper and lower half of each centre call out the names of the localized ancestral spirits, whereby the officiant at the upper half of each centre calls upon the 'names of the domain' of the lower half of the domain and that of the lower half of each centre calls upon those of the upper half of the domain, in line with their respective spheres of influence.

In that context Opa not only asserted his own position, but strongly contested the position of the priest-leader of the second centre. ${ }^{19}$ Immediately after having concluded the kao pollo ritual at his centre, he climbed onto the mound of the second ceremonial centre and stated that there really was only one Ko'a priest-leader ('there is really only one mother, there is really only one father'). After which he, rather than the priest-leader of that centre, proceeded to conduct the kao pollo ritual. Such a move effectively amounted to a usurpation of the position of the second priest-leader of the domain and clearly called for a strong response from Lopo.

Once the kao pollo has been carried out, the stage is set for a different type of event. Due to the ancestral presence and the presence of the Supreme Being in the Ko'a villages, every act and every word acquires a heightened valency. Every night both centres become the stage for a particular type of dancing and chanting (togo tio pata, literally, to dance and chant). The chants follow prescribed structures. They are largely metaphoric and employ a vocabulary, which is mostly different from everyday speech. These chants provide an important channel to air grievances publicly, or to taunt and tease adversaries. Preceding the 1970s, such dances were also frequently held outside the context of the cycle. The local government eventually forbade them because they were perceived as a source of discord within the community. Chanting and dancing 
of this type is now reserved exclusively for the ceremonial cycle and confined to the two centres of the domain. Words chanted on those occasions and in the presence of the ancestors and the Supreme Being acquire a quasi-legal character. A given chant is repeated over and over again, until there is an acceptable reply. The chants generally are deliberately opaque and allusions to a particular event or an offence in question mostly are veiled, thus designed to incite replies from more than one party.

During the night following the incident of the kao pollo ritual, such a chant was being rehearsed at Lopo's centre. ${ }^{20}$ The chant was uncharacteristically direct, in that it did not leave any doubt about the issue in question, nor about the persons to whom it is addressed. In this chant, the prominent Ko'a chanter and poet Woko made allusion to his unsuccessful voyage to Malaysia to seek out Opa's children Mia Poké and Sundu. This he chanted on his own account, in line with his own position as wife-taker to Opa's origin group. Woko also chanted on behalf of Lopo, the second Ko'a priest-leader who had married Toci, one of Lisé's sisters. This part of his chant dealt with issues of bridewealth between the two Ko'a groups of first settler status. Essentially it accuses the wife-givers of failing to reciprocate in exchange. The chant goes as follows:

I ask Meno Tana [Opa's centre] to reciprocate.

The [marriage] path is bent,

the child goes in circles,

the child goes in circles,

come quickly and reciprocate.

I was to go north [to Malaysia],

to find Opa's daughter Poké,

or was I to go to the north [to Opa's centre],

where Lopo's [wife] Toci came from ?

The gifts you carried were not enough.

Malaysia is so large you can look for ever,

I went over there to look for Opa's children.

Opa was tired of waving and calling

for the male (his son) to come back from the north.

I went all the way from here to the north,

to call back the male from Powo Wawo [Opa's origin place].

I am calling for the male [the priest-leader],

to come across to Manggé Basé [Lopo's] centre,

to see for himself.

We have seen one side of the moon,

now we need to see the other.

I ask for your gift at your offering place [Opa's centre].

Ndasa's husband [one of Opa's brothers] is north as well.

Oh, the drums follow the ankle bells, 
oh, Opa's drums have no voice,

oh the drums of Taku Tolé have no voice.

Marriage alliance on Palu'é is effected through the exchange of gendered goods. The wife-taking house, together with the other houses of its origin group, makes prestations of conceptually male goods to the wife-giving house. These consist of large pigs, golden ear pendants, ivory tusks and money. The wife-giving house and the constituent houses of its origin group reciprocate with conceptually female goods consisting of textiles, harvest goods, furniture, ivory arm rings and a particular type of ancestral beads that can also be substituted by land. The amount of goods to be exchanged is negotiated and so is the time schedule of instalments. At every instalment the resources of the two origin groups involved are pooled, and the goods received are redistributed among the participating houses. Instalments usually take place over an extended period of time and can go beyond the life span of the couple in question, thereby extending obligations between wife-givers and wife-takers to the following generation. The very end of these exchanges is marked by a partial inversion. Once the wife-taking house has made its last major prestation, the wife-giving house reciprocates not only with conceptually female goods, but also with a large-sized male pig. This final prestation is referred to as 'to bring across the fish' (mboro ika), thereby obfuscating the categorical inversion.

In the marriage alliance between the houses of Lisé and Lopo, Lisé over the years had already received his share of bridewealth. The final prestation of a large sized pig and a set of golden ear pendants, therefore, was made to Opa's house, as the senior house of the wife-giving origin group. At the time, Opa accepted these goods from Lopo, thereby implying that he would reciprocate with the mboro ika pig. However, when the time came to reciprocate, he refused to do so, on the grounds that Lopo's prestations had been insufficient. On an everyday basis, his refusal caused a lot of tension between the origin groups involved, but because Lopo as a wife-taker was subordinate to his wife-giver, specifically in the context of alliance related exchange, he was not in the position to exert any significant pressure on Opa.

Issues of reciprocity in exchange are a frequent topic of the type of chanting that takes place during the cycle. Often they lead to one party making amends on the very morning following the chanting. The chant created by the poet Woko on behalf of Lopo was, therefore, not unusual. What was somewhat unusual was the directness in which this chant was formulated. In this particular case, the chant was formulated in such a transparent and direct fashion, in contravention of the highly valued stylistic conventions of opaqueness, that Opa felt he had been publicly affronted by his wife-taker. During the opening phase of the ceremonial cycle, the members of Lopo's centre chanted this chant on several occasions at Opa's centre, without receiving a satisfactory reply. 
Opa did eventually reply to this chant. ${ }^{21}$ His chant simply stated what he had already said on previous occasions, that Lopo's prestations had been insufficient and that he, therefore, did not feel bound to reciprocate. Unlike Woko's blunt and direct chant Opa's chant maintained a certain degree of opaqueness by using metaphors as well as semantic inversion, allowing for multiple interpretations, rather than just one evident interpretation.

Male male male, widows and orphans.

I, the priest-leader, speak to you widows and orphans,

I, the priest-leader, speak to you the people of Ko'a.

Together we made the right sacrifice up at the volcano,

it lies there visible to [the ancestors inside] the volcano.

Up at the volcano my blood pours down,

I am outside, my soul is watching.

No sooner was I offered, that my soul flew away.

My soul has disappeared, have you seen it anywhere?

At one level of interpretation, the chant deals with the incest sacrifice conducted at the volcano and by extension also with the other preliminary sacrifices. In all cases, Opa felt the carcasses had been scavenged too soon after the sacrifices for the blood to penetrate fully into the ground, thereby diminishing the efficacy of the ceremony. He chanted that his soul, lobo, was displaced through the scavenging. At another level of interpretation, the term can also be understood as word play on the name of Lopo (the letter $\mathrm{p}$ in the name is implosive, whereas the letter $b$ in the term for soul it is not), the second Ko'a priest-leader. In such an interpretation, the chant alludes to the issue of outstanding bridewealth and to Lopo's insufficient prestations. Whatever the case may be, Lopo did not create a further chant to reply to Opa's chant and he also did not continue to chant the chant Woko had created on his behalf. The Ko'a poets and specialists of chanting, therefore, concluded that Lopo had accepted the chant.

\section{Popular Resistance and Priest-Leadership}

Interestingly, at the very same time at which Opa was chanting this chant, bridewealth negotiations were being conducted between some Ko'a houses and some houses of a neighbouring domain right next to Opa's centre. ${ }^{22}$ Such negotiations are often major social events, involving large numbers of guests. Usually they are not held in conjunction with the ceremonial activities of the water buffalo sacrificing cycle, because all houses of the domain are supposed to use their resources for catering to the guests attending the dances, rather than for other purposes. This intention is rather more pronounced at the end of the cycle. Once the final sacrifice is under way, no large scale undertakings involving 
exchange, such as the construction of houses or boats, may be undertaken, until the pole onto which the skull of the sacrificed animal has been fastened has decayed and fallen over. This process may take several years, the end of which is ritually marked by the priest-leader. The negotiations in question were being conducted by houses not holding first settler status, and the very fact that they were conducted at that point in time and at that particular place is suggestive of resistance among the 'child people' of the domain against the continuous assertions and contestations of positions of precedence among its 'father people'.

In the course of the opening phase of the cycle, there had been a number of issues to which the people of Ko'a objected. The extension of sanctions for incest among first settlers to include all members of the domain had not been well received, since it involved bringing in sacrificial water buffaloes from Flores at a cost that few houses could afford, rather than the customary slaughtering of a pig. Given that accusations of incest among first settlers were handled in a somewhat arbitrary manner, the new sanctions were perceived as a serious economic threat. Those who were not engaged in labour migration to Malaysia and who by that very fact were not affluent, would be liable to be held to account for the doings of the absent members of their house, as had been the case with Rugu and Sundu, the father and father's brother of the siblings who had conceived a child in Sabah.

Another measure to which the people of Ko'a objected was the closing of a path leading up the mountain, which Opa had announced as a measure to protect his place of origin against uncontrolled burning. This path was important to all those, whose gardens lay in the upper half of the domain. Though there was an alternative route that followed the bottom of an erosive gully, this represented a significant detour, which was highly inconvenient, since on Palu'é all goods must be carried.

A third point of contention was the unresolved issue of bridewealth exchange in the marriage alliance between Lopo and Lisé's sister. This marriage alliance between the two houses of first settler status not only concerned their respective origin groups, as is usually the case, but it affected virtually the whole of the domain. Just about every house of the domain was involved in this exchange, either on the side of the wife-givers, or then on that of the wife-takers, simply by virtue of having supported one or the other side with goods of the appropriate category. Any dissonance in the conclusion of the extended process of bridewealth exchange between the two first settling groups of the domain was, therefore, a source of discontent to all members of the domain.

Only few days after the poet Woko had chanted his chant on behalf of Lopo, he created a new chant while he was engaged in the tapping of a lontar palm tree, this time on behalf of the people of Ko'a. ${ }^{23}$ His new chant was welcomed in Ko'a because it expressed the general feeling about the politics of marriage 
alliance between the priest-leaders of the two centres. Through Woko's voice, the people of Ko'a appeared to be contesting not only Opa's precedence, but that of both priest-leaders of the domain. In his chant he reminded the priest-leaders of their dependence on the people of the domain. The chant mainly addressed the issue of bridewealth, but its implications went well beyond that. Although it stated that the priest-leaders needed their people as partners in marriage alliance, the implication was that without the people of Ko'a there could be no priest-leaders, no water buffalo sacrificing cycles and ultimately no domain. As it is put in the idiom of the father child relationship between first settlers and subsequent settlers, 'a father needs $<$ his $>$ children, $<$ as much as $>$ children need a father'. As Woko was chanting, he was overheard by other men tapping in the vicinity, and the news about the chant travelled across the island even before Woko had returned home from tapping. His chant will be repeated perhaps for years, until the priest-leaders of Ko'a create a reply that the people of Ko'a accept.

Oh, let's chant!

You have been fooling all of us with your marriage alliance.

I descend on the offering place [Opa's ceremonial centre],

I fly to the offering place.

The people rush to the offering place,

the male [priest-leader]

and the widows and orphans.

The male needs the women of eight [the people],

in future who can the priest-leaders find to marry?

I have said it before,

the return gift [to Lopo] is still missing.

Oh Nata Ca [Opa's settlement],

we wish to see your gift,

how can we follow you?

This is what I have come to ask you at your centre.

At least Ratu Cavané [the ethnographer] got Poké

[Opa's daughter] back.

She had been stalling and delaying [in Malaysia].

Oh, where did you put Toci [Lopo's wife]?

I will say it again and again

at your place of offering,

until I can no longer say it.

Holding a primary position within an order of precedence does not necessarily convey priest-leadership, as the case of Lisé amply demonstrated. Although priest-leadership on Palu'é is ascribed, in that generally only the first-born son of the senior first settling house is eligible for priest-leadership, much depends on the personal abilities such an individual brings to the office, and on the 
amount of approval and recognition that can be generated among the members of the domain and its allies, whether such a person actually can take up priest-leadership and whether that person can retain that office over time. One of the important functions of a priest-leader is to adjudicate on customary matters and, therefore, a candidate must be knowledgeable about customary law (huku pata) and even handed in his dealings with people. Extensive knowledge of hada, the ancestral corpus of knowledge, is another precondition for priest-leadership, particularly in the realms of the rituals of the centre, ritual speech, bridewealth negotiation, mythology and the history of the domain and its houses. Such knowledge is usually transmitted over many years from a priest-leader to the first-born son. A priest-leader approaching old age will begin to delegate matters connected with his office to that son, in order for the son to gain experience and also in order for him to gain gradually acceptance and authority in the domain. A son who does not have the abilities necessary for the office may be overlooked in favour of a different member of that house and failing that, even in favour of a member of a different house of the first settling origin group in question. This is probably what happened several decades ago in the case of Lisé, after the former main Ko'a priest-leader had died.

Approval by the priest-leaders of the allied domains is another important factor in securing priest-leadership. This used to be a lot more important in the past, when every closure of a ceremonial cycle was followed by disputes over boundaries shared with non allied domains. Such disputes more often than not escalated into warfare, and there the support from allied domains was absolutely crucial. Currently alliances between domains mainly have a bearing on the quality of a ceremonial cycle and the prestige with which a given domain emerges from its cycle. If the allies have attended the nightly dances over the months preceding the final sacrifice and if they have been catered to appropriately, then a hosting domain may assume a position of precedence with respect to its allies, a relationship which is expressed in terms of gender classification. A hosting domain thus can change its status from female to superordinate male and exercise influence on matters pertaining to the alliance, in line with its position of precedence among its allies (see Vischer 1996b).

It appears that priest-leadership can even be acquired, regardless of the status of the house of the holder, as in the case of Lopo's house that replaced the ousted former priest-leader and his origin group. Although Lopo's house at this point has not yet established firmly its position as a first settling house, partly because the transition occurred rather recently during Lopo's father's father's time, but certainly because of the lack of knowledge in customary matters displayed by Lopo, it may be only a matter of time for the links to his former origin group to be forgotten and for his house to create mythological connections or a historical narrative that more solidly establishes its identity as first settlers. 
Priest-leadership and even first settler status also can be forfeited, as had been the case with the ousted sacrificers of the second ceremonial centre in Ko'a. In the Palu'é domain of Tua Nggéo there is currently only one priest-leader. The second ceremonial centre of that domain has been in disuse for several decades and its custodians no longer exercise priest-leadership. The reason given for this by the current main priest-leader is that the former priest-leader of the second Tua Nggéo centre had become 'embarassed' (méa). Although this is not further elaborated upon, the implications are that the former priest-leader was not up to the task and neither was any other male member of his house or origin group. This is where a chant such as the one created by Woko over time may effect a change in the order of precedence of the domain. If, for one reason or another, the flow of approval of the members of a domain and its allies ceases, then a priest-leader becomes highly vulnerable and eventually he may even lose his position. When three cycles ago Lisé made a bid for Ko'a priest-leadership by sponsoring a ceremonial cycle and purchasing sacrificial water buffalo, he could only do so because Opa had lost the approval of the members of his domain and that of its allies. However, approval alone is insufficient for priest-leadership. Lisé failed not simply because his sacrificial water buffalo did not survive. He failed because, in spite of being structurally in the right position, he lacked one absolutely crucial element of priest-leadership.

A significant part of Palu'é priest-leadership is achieved. A given priest-leader who is successful in ensuring the welfare of the domain is believed to have a privileged relationship with the collective ancestral spirits and with the Supreme Being. Of such a person it is said that 'he has $<$ a special relationship with $>$ the Sun and the Moon' (that is, a special relationship with a particular aspect of the Supreme Being) and he is feared, respected and loved for this very reason. If a priest-leader is not successful, it is said that 'the sun and the moon are not with him'. Eventually such a priest-leader will lose the support of the members of the domain to conduct a ceremonial cycle. In illness, a healer sorcerer or a medical practitioner, rather than the priest-leader will be contacted. Periods of ritual restrictions on agriculture will no longer be respected and legal issues will be put directly to the district courts, rather than being dealt with by him in the first instance. At the time of Lisé's bid, Opa was able to resume priest-leadership in Ko'a because the premature death of the sacrificial animal had indicated to the members of the domain that Lisé did not have a privileged relationship with the supernatural, that is, that 'the Sun and the Moon were not with him'. Opa, on the other hand, may not always have had the approval of the members of his domain, but time and again he had proven that he had a very special relationship with the 'Sun and Moon' (see Vischer 1992). The benefits of having someone in charge in the domain who had these particular qualities, in that instance apparently outweighed the fact that every now and then that person made unpopular decisions that affected all of the domain. 


\section{Concluding Remarks}

With regard to the ethnography of the domain of Ko'a, it has been demonstrated here that precedence as an analytic concept can bring together a whole range of diverse realms (such as issues involving ritual, cosmology, mythology and sacrifice, issues of incest, labour migration, child transfer or adoption, issues of succession, mortuary prescriptions, issues of ceremonial maturity and eligibility, marriage alliance, issues of reciprocity and exchange, leadership, political rhetoric as well as poetics) that in another mode of analysis perhaps would not be easily recognized as interconnected.

The application of the analytic concept of precedence to key events taking place in the context of the Ko'a ceremonial cycle and the tracing of their individual histories has provided insights into processes of social differentiation, involving the establishment, assertion and contestation of unequal or asymmetric relations, which are characteristic to Austronesian societies and which another mode of analysis would probably not have arrived at. This establishes the practical value of this analytic concept for the comparative study of Austronesian social life.

\section{References}

Fox, James J.

1995 Origin structures and systems of precedence in the comparative study of Austronesian societies. In P.J.K. Li, Cheng-hwa Tsang, Ying-kuei Huang, Dah-an Ho and Chiu-yu Tseng (eds), Austronesian studies relating to Taiwan, pp.27-57. Taipei: Symposium Series of the Institute of History \& Philology: Academia Sinica 3.

Kelly, R.

1993 Constructing inequality: the fabrication of a hierarchy of virtue among the Etoro. Ann Arbor: The University of Michigan Press.

Lewis, E.D.

1988 People of the source: the social and ceremonial order of Tana Wai Brama on Flores. Verhandelingen van het Koninklijk Instituut voor Taal-, Landen Volkenkunde 135. Dordrecht, Holland/Providence, USA: Foris Publications.

Platenkamp, J.

1988 Tobelo: ideas and values of a North Moluccan society. Leiden: University of Leiden. 
Vischer, M.P.

1992 Children of the black patola stone: origin structures in a domain on Palu'é Island (Eastern Indonesia). Unpublished $\mathrm{PhD}$ thesis. Canberra: Department of Anthropology, The Australian National University.

1996a Contestations: dynamics of precedence in an eastern Indonesian domain. 55 mins videorecording (P. Asch, ed.) Canberra: The Australian National University/Leiden: International Institute for Asian Studies.

1996b Precedence among the domains of the Three Hearth Stones: contestation of an order of precedence in the Ko'a ceremonial cycle (Palu'é Island, eastern Indonesia). In James J. Fox and Clifford Sather (eds), Origins, ancestry and alliance: explorations in Austronesian ethnography, pp.175-198. Canberra: Department of Anthropology, Research School of Pacific and Asian Studies, The Australian National University. Comparative Austronesian Series, ANU E Press: http://epress.anu.edu.au/.

1996c Early Austronesian social structure in the light of the Ko'a social order. In P. van der Velde (ed)Yearbook of the International Institute for Asian Studies 1995. Leiden: International Institute of Asian Studies.

2001 Substitution, expiation and the idiom of blood. Journal of the Finnish Anthropological Society 3:30-44.

\section{ENDNOTES}

1 The parameters of comparison have been defined linguistically. For our present purposes they are confined to the world of speakers of the Central Malayo-Polynesian Subgroup (CMP) of the Austronesian language family (that is, the two dozen or more languages of Flores, Sumba and Timor in the eastern part of Indonesia). The contention is, however, that what is being said about CMP speakers with regard to precedence also holds true to varying degrees for that family as a whole. As was to be expected, research into groups located in Austronesian border areas has revealed a considerable cultural overlap on both both sides. See for instance Platenkamp 1988. These findings do not diminish the value of this informed comparative approach. They do, however, raise questions as to what exactly the characteristic features of Austronesian societies might be, an issue, which clearly requires further research.

2 The case under investigation was documented extensively by videographic means in late 1994 and early 1995. Some of this footage subsequently was edited by the ethnographic filmmaker Patsy Asch at the Ethnographic Film Unit of the Department of Anthropology at the Research School of Pacific and Asian Studies (The Australian National University) and made into a social anthropological film for teaching about the analytic concept of precedence. The film 'Contestations' (Vischer 1996a) depicts a series of contestations and assertions of the order of precedence of the domain of Ko'a, which took place in the context the opening phase of its water buffalo sacrificing cycle.

3 The tentative analysis made in 'Contestations' was to a large degree confirmed in the feedback sessions. The participants agreed that in terms of precedence the film not only showed all of the crucial events of the opening of the cycle, but that they had been represented appropriately. As it turned out, the extensive discussions triggered by the images mainly added depth to the analysis, rather than suggesting significantly different interpretations from those already offered in 'Contestations'.

4 The film 'Contestations' deals with the opening phase of the cycle, as does this contribution. A sequel dealing with the closing phase of the cycle is in post production.

${ }^{5}$ I presented the first results of my analysis in a paper I gave in 1990 at a conference on Austronesian hierarchy hosted by the Department of Anthropology at the Research School of Pacific Studies of The 
Australian National University (Vischer 1996b). The paper was essentially an event oriented analysis with a particular focus on precedence relations between allied domains. In my doctoral thesis I then went on to describe the constituent elements of precedence in Ko'a, which I collectively referred to as origin structures (Vischer 1992), in an extension of the term as it had been introduced by Fox (Fox 1995). In a paper published in the 1995 Yearbook of the International Institute of Asian Studies (IIAS) in Leiden (Vischer 1996c) I traced some of the origins of precedence studies and indicated their position in social anthropological theory.

6 In ritual speech, the subordinate position of the younger brother is aptly described as: 'the elder brother receives the guests // the younger brother prepares the lontar palm leaves for smoking'.

7 See Contestations: 0.11.28 - 0.14.30. References to the film 'Contestations' (Vischer, 1996a) indicate hours, minutes and seconds.

8 In disputes over inheritance the Flores district courts use the criterion of who has paid for the mortuary costs to decide who will be awarded rights.

9 Here precedence may link up with the moral hierarchy or hierarchy of virtue proposed by Kelly (1993) for the Etoro of Papua New Guinea.

10 See 'Contestations', $0.31 .00-0.31 .20$.

11 Interestingly, many of those present on the beach and certainly some of the people on the capsizing boat must have been aware of the fact that actually it had been my second camera operator who had capsized the boat by positioning himself wrongly, as he was trying to film the unloading. This more obvious line of argumentation was taken up by none of the parties, because the collective focus at that time clearly was on issues of precedence rather than elsewhere.

12 See 'Contestations': $0.34 .05-0.35 .57$.

13 According to some reports, there used to be a lake inside the Palu'é volcano, similar to the three famous volcanic lakes of Kélimutu on Flores. Volcanic activity appears to have been the cause of its disappearance.

14 See 'Contestations': $0.00 .25-0.02 .41$.

15 Another aspect of this has to do with the latent antagonism between sacrifiers and sacrificers of that centre. This antagonism is most prominent during the closing phase of the ceremonial cycle. At the closure of the cycle, when sacrifiers and sacrificers ready themselves for the final sacrifice of the 'water buffalo of the domain', the antagonism is expressed in rules of avoidance. At that moment, sacrificers are said to be conceptually hot and dangerous, in line with their ritual office, whereas sacrifiers are supposed to be conceptually cool and beneficial, as is the animal they are offering to the Supreme Being.

16 See 'Contestations': $0.38 .31-0.39 .10$.

17 See 'Contestations' $0.33 .05-0.33 .42$.

18 See 'Contestations': 0.26 .00$.

19 See, 'Contestations': 0.39.37-0.42.05.

20 See 'Contestations': $0.42 .36-0.44 .40$.

21 See 'Contestations' 0.46 .20 - 0.46.40, 0.47.49 - 0.48.30.

22 See 'Contestations': $0.46 .38-0.47 .30$.

23 See 'Contestations': $0.48 .31-0.51 .23$. 